\title{
Febrile temperatures increase in vitro antibody affinity for malaria and dengue antigens
}

\author{
Authors: Razvan C. Stan ${ }^{a 1}$, Katia S. Françoso ${ }^{b}$, Rubens P.S. Alves ${ }^{c}$, Luís Carlos S. Ferreira ${ }^{c}$, Irene S. Soares ${ }^{b}$, \\ Maristela M. de Camargo ${ }^{\mathrm{a} 1}$ \\ ${ }^{a}$ Department of Immunology, Institute for Biomedical Sciences, University of São Paulo, 05508-900, Brazil. \\ ${ }^{b}$ Department of Clinical and Toxicological Analysis, School of Pharmaceutical Sciences, University of São \\ Paulo, 05508-000, Brazil. \\ ${ }^{\mathrm{c}}$ Department of Microbiology, Institute for Biomedical Sciences, University of São Paulo, 05508-000, Brazil. \\ ${ }^{1}$ Corresponding authors
}

\begin{abstract}
:
Fever is a regulated elevation in the body setpoint temperature and may arise as a result of infectious and noninfectious causes. While beneficial in modulating immune responses to infection, the potential of febrile temperatures in regulating antigen binding affinity to antibodies has not been explored. We have investigated this process under in vitro conditions using selected malaria or dengue antigens and specific monoclonal antibodies, and observed a marked increase in the affinity of these antibody-antigen complexes at $40^{\circ} \mathrm{C}$, compared to physiological $\left(37^{\circ} \mathrm{C}\right)$ or pathophysiological temperatures $\left(42^{\circ} \mathrm{C}\right)$. Induced thermal equilibration of the protein partners at these temperatures, prior to measurements, further increased their binding affinity. These results may indicate an unexpected beneficial and adaptive role for fever in vivo, and highlight the positive role of thermal priming in enhancing protein-protein affinity for samples of scarce availability.
\end{abstract}

\section{Keywords:}

Fever, malaria, dengue, antibody affinity, thermal equilibration 
Maintaining a constant temperature in mammals is a tightly regulated process, including in cases where infections occur and body temperature increases. Fever, an initial, nonspecific, acute-phase response during infections, is a key factor responsible for improving survival and shorten disease duration (1). Cellular events occurring during physiological fever or hyperpyrexia have been the focus of intensive clinical and in vitro studies (2). Previous research has revealed that fever-inducing pathogen load is reduced due to enhanced host defence while its proliferation at febrile temperatures is not significantly affected. (3). Physiological and reversible increases in core body temperatures do not normally exceed the $40^{\circ} \mathrm{C}$ threshold (4), with survival beginning to decrease when fever exceeds $39.5^{\circ} \mathrm{C}$, suggesting that there is an upper limit to the optimal fever range (5).

While elevated temperatures profoundly alter membrane fluidity, cell signalling and gene expression patterns, the role of febrile temperatures in directly affecting antibody affinity for antigens from pathogens that induce fever has not been explored. We have focused here on the in vitro changes of binding affinities for two antibody-antigen immune complexes characteristic of two widespread, fever-inducing infectious diseases $(6,7)$. To this end, we made use of antigens from a viral agent, i.e. non-structural protein 1 (NS1) from dengue virus serotype 2 DENV-2 (8), and from a protozoan pathogen, namely the 19-kDa carboxyterminal region of merozoite surface protein $1\left(\mathrm{MSP}_{19}\right)$ from Plasmodium vivax (9), and their corresponding monoclonal $\operatorname{IgG}$ antibodies $(10,11)$.

Antibodies progressively mature their affinity and specificity for various target antigens by changing the amino acid residue composition of their complementarity-determining regions (12). As with other proteins, high affinity can be achieved by fast association rates coupled to slow off-rates in a process directly dependent, among other factors, on temperature. The thermal optimum of antibody-antigen complex depends on the chemical nature of the epitope and paratope, and on the type of bonds formed at different temperatures (13). The effect of fever temperature on equilibrium constants of immune complexes formed by erythrocyte antibodies has previously uncovered very modest decreases from $2.2 \cdot 10^{7} \mathrm{M}^{-1}$ at $15 \square-19^{\circ} \mathrm{C}$ to $1.8 \cdot 10^{7} \mathrm{M}^{-1}$ at $37 \square-40^{\circ} \mathrm{C}(14)$.

\section{Results}

Isothermal Titration Calorimetry (ITC) and ELISA measurements. We carried out with ITC a systematic investigation into the formation of dengue and malaria immune complexes at $37^{\circ} \mathrm{C}, 40^{\circ} \mathrm{C}$, and $42^{\circ} \mathrm{C}$. Prior to measurements, we have equilibrated in vitro at indicated 
temperatures all the proteins for 1 hour (Supporting Information). This procedure was carried out in order to subject the partner proteins to temperatures more relevant to those caused by fever-inducing pathogens and for periods that in vivo are not lethal (e.g. less than 6 hours at $41 \square-42 \square$ ) for P. vivax infections) (15). Representative ITC thermograms are shown in Figure 1.
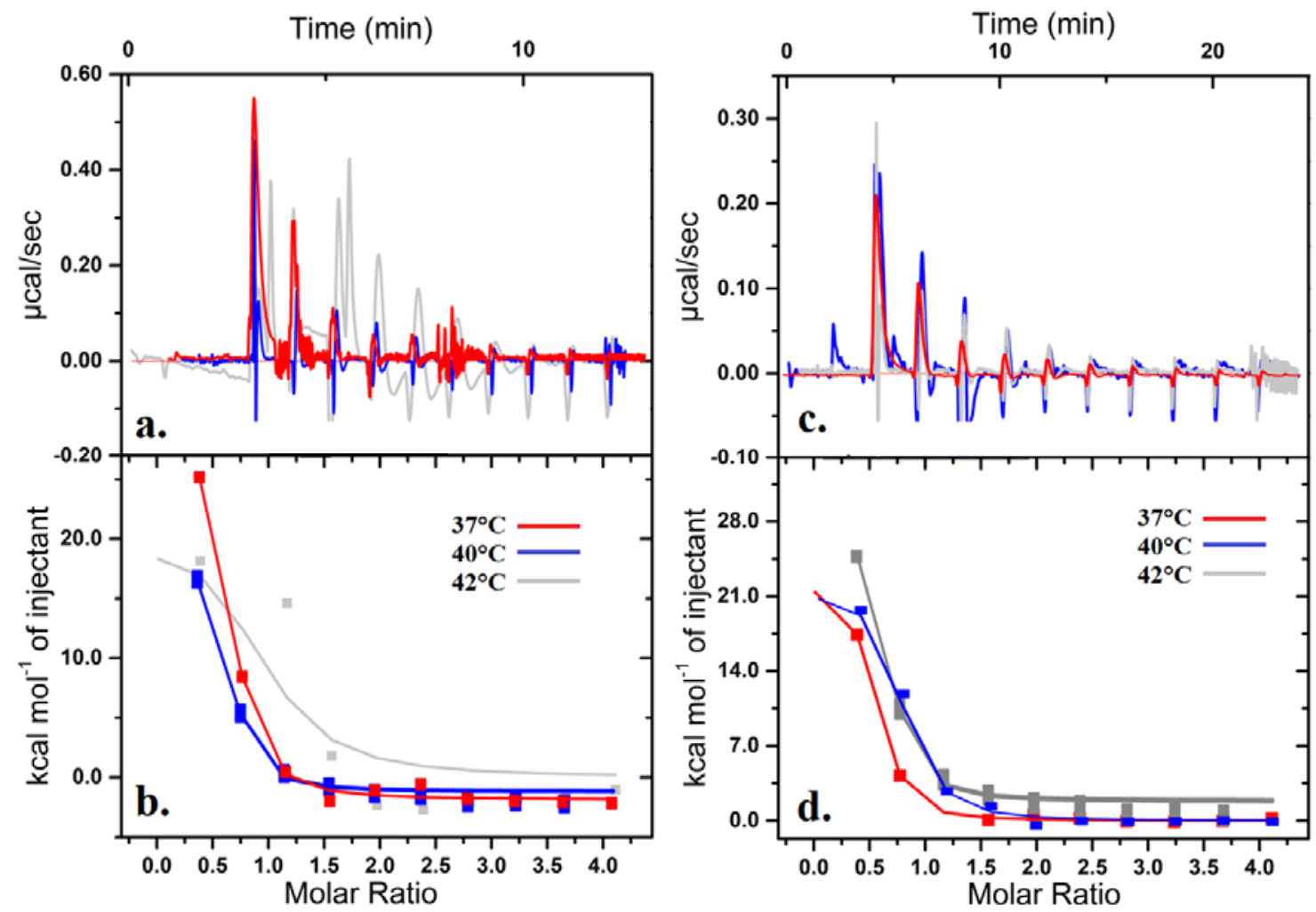

Fig. 1. ITC measurements of malaria $\mathrm{MSP}_{19}$ titrated into $\mathrm{K}_{2} 3 \mathrm{IgG}$ antibody (a-b) and DENV-2 NS1 titrated into 4H1BC IgG1 antibody (c-d) at indicated temperatures. Results fitted to a single-binding site model with 1:1 stoichiometry.

The changes in enthalpy with increases in temperature are nonlinear, characterized by lowest values at $40^{\circ} \mathrm{C}$ for both systems, followed by a more negative change at $42^{\circ} \mathrm{C}$ and a further decrease at $37^{\circ} \mathrm{C}$ (DENV-2), while the opposite is present for the malaria immune complexes (Figure 1). A common feature that we measured for both systems was an increase in binding affinity at $40^{\circ} \mathrm{C}$ compared to other temperatures, as measured in solution by ITC, or in solidphase assay with ELISA, as presented in Figure 2. 

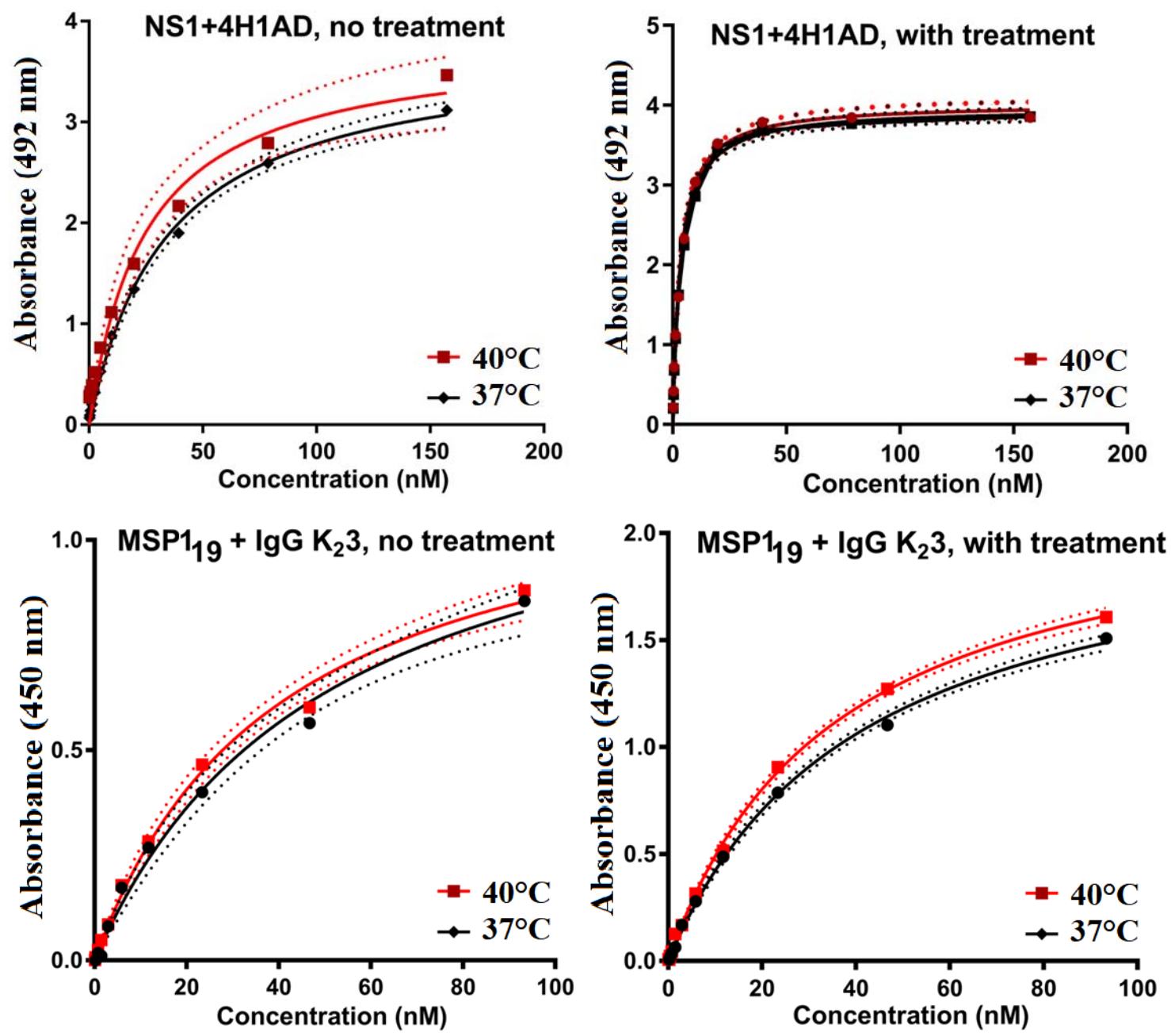

Fig. 2. Upper panel: ELISA measurements of dengue DENV-2 NS1 antigen with IgG1 4H1BC, without (a) or with (b) a thermal pre-equilibration step. Lower panel: ELISA measurements of malaria MSP1 ${ }_{19}$ antigen with IgG $\mathrm{K}_{2} 3$, without (c) or with (d) a thermal treatment procedure at indicated temperatures.

For both immune complexes, ELISA measurements showed a $\sim 1.15-1.3$ increase in affinity from $37^{\circ} \mathrm{C}$ to $40^{\circ} \mathrm{C}$, in the presence or absence of thermal priming. However, thermal preequilibration led to significant improvements in $\mathrm{K}_{\mathrm{D}}$ by a factor of $\sim 9.5$ (at $37^{\circ} \mathrm{C}$ ) and $\sim 8$ (at $40^{\circ} \mathrm{C}$ ) for the dengue immune complex, and to a decrease in $\mathrm{K}_{\mathrm{D}}$ by a 1.3 factor (at $37^{\circ} \mathrm{C}$ ) and a 1.2 factor at $40^{\circ} \mathrm{C}$, respectively for the malaria complex. An overview of ITC and ELISA results is shown in Table 1. 
Table 1. Thermodynamic and kinetic data of dengue and malaria immune complexes

\begin{tabular}{lcccccc}
\hline \multicolumn{1}{c}{ Parameters } & $\begin{array}{c}\text { Dengue } \\
\text { complex }\left(37^{\circ} \mathrm{C}\right)\end{array}$ & $\begin{array}{c}\text { Dengue } \\
\text { complex }\left(40^{\circ} \mathrm{C}\right)\end{array}$ & $\begin{array}{c}\text { Dengue } \\
\text { complex }\left(42^{\circ} \mathrm{C}\right)\end{array}$ & $\begin{array}{c}\text { Malaria } \\
\text { complex }\left(37^{\circ} \mathrm{C}\right)\end{array}$ & $\begin{array}{c}\text { Malaria } \\
\text { complex }\left(40^{\circ} \mathrm{C}\right)\end{array}$ & $\begin{array}{c}\text { Malaria } \\
\text { complex }\left(42^{\circ} \mathrm{C}\right)\end{array}$ \\
\hline $\mathrm{K}_{\mathrm{D}}[\mathrm{nM}]$ (ELISA) & $33.3 \pm 2.8$ & $25.4 \pm 4.1$ & $12.3 \pm 1.3$ & $51.2 \pm 2.4$ & $39.9 \pm 3.3$ & $47.8 \pm 2.8$ \\
$\mathrm{~K}_{\mathrm{D}}[\mathrm{nM}](\mathrm{ELISA}) *$ & $3.5 \pm 0.2$ & $3.1 \pm 0.13$ & $\mathrm{NA}$ & $40.4 \pm 2.2$ & $35.3 \pm 1.7$ & $\mathrm{NA}$ \\
$\mathrm{K}_{\mathrm{D}}[\mathrm{nM}](\mathrm{ITC}) * *$ & $9.8 \pm 1.8$ & $3.56 \pm 0.9$ & $17.2 \pm 1.5$ & $50.5 \pm 3.1$ & $23 \pm 4.6$ & $43 \pm 1.2$ \\
$\Delta \mathrm{H}[\mathrm{kcal} / \mathrm{mol}]$ & $14.6 \pm 1.2$ & $18.5 \pm 2.1$ & $23.2 \pm 2.9$ & $29 \pm 2.3$ & $19.4 \pm 1.3$ & $22 \pm 1.7$ \\
$\mathrm{~T} \cdot \Delta \mathrm{S}[\mathrm{kcal} / \mathrm{mol}]$ & $25.7 \pm 3.2$ & $30.6 \pm 2.2$ & $35.1 \pm 1.9$ & $33.2 \pm 1.1$ & $27 \pm 3.1$ & $28 \pm 2.4$ \\
$\Delta \mathrm{G}[\mathrm{kcal} / \mathrm{mol}]$ & $-11.1 \pm 3.4$ & $-12.1 \pm 3.1$ & $-11.9 \pm 3.5$ & $-4.2 \pm 2.4$ & $-7.6 \pm 3.3$ & $-6 \pm 2.9$ \\
$\mathrm{k}_{\text {on }}\left[10^{6} \mathrm{M}^{-1} \cdot \mathrm{s}^{-1}\right]$ & 6.12 & 36.5 & 6.9 & 1.2 & 3.9 & 1.8 \\
$\mathrm{k}_{\text {off }}\left[\mathrm{s}^{-1}\right]$ & 0.6 & 1.3 & 0.12 & 0.06 & 0.09 & 0.08 \\
$\Delta \mathrm{C}_{\mathrm{p}}[\mathrm{kcal} / \mathrm{mol} \cdot \mathrm{K}]$ & & $-3.5 \pm 0.73$ & & & $0.46 \pm 0.08$ &
\end{tabular}

*Values for thermally pre-equilibrated samples. **Thermodynamic and kinetic data calculated with kinITC (Affinimeter, SP). NA -data not available. Thermodynamic values represent averages with standard deviations.

\section{Discussion}

ITC measurements for the dengue system at $40^{\circ} \mathrm{C}$ revealed a $\mathrm{K}_{\mathrm{D}}$ lower by a factor of $\sim 2.8$ compared to values at $37^{\circ} \mathrm{C}$ and correspondingly by a factor of $\sim 5$, compared to measurements at $42^{\circ} \mathrm{C}$. The main contribution to binding affinity is entropic, with the highest value measured at $42^{\circ} \mathrm{C}$, being compensated by large positive enthalpy variations. The intrinsic free energy of binding was largely independent of temperature variations, reflecting the compensation of the enthalpic and entropic terms. Kinetic parameters were largely responsible for the differences in affinities observed across temperatures, with much faster $\mathrm{k}_{\text {on }}$ rates measured at $40^{\circ} \mathrm{C}$, especially when compared to values at $42^{\circ} \mathrm{C}$ ( $\sim 11$ fold increase). Epitope-mapping studies have identified the sequence ${ }^{193}{ }^{A V H A D M G Y W I E S A L N D T}{ }^{209}$ as the conformational epitope buried within a $\beta$-sheet structure of the dengue NS1 protein (16). The presence therein of net three negative charges conferred by the aspartic and glutamic acid residues may result in more stable immunocomplexes at higher temperature, as previously measured in other systems (17). The negative grand average of hydropathy indicates a hydrophilic interface for this immune complex, whose hydration on temperature increase lies (18) at the origin of the observed negative heat capacity. Importantly, the effect of temperature changes in modulating monoclonal antibodies binding to DENV-2 antigens was also shown to be important for its structural $\mathrm{E}$ proteins (19). Unique quaternary conformational epitopes were exposed when virions were incubated at vertebrate host physiological temperature $\left(37^{\circ} \mathrm{C}\right)$, versus the mosquito thermal optimum of $28 \square-30^{\circ} \mathrm{C}(19)$. ITC measurements for the malaria complex showed a $\mathrm{K}_{\mathrm{D}}$ approximately $\sim 2.1$ and $\sim 1.8$ folds lower at $40^{\circ} \mathrm{C}$ when compared to values at $37^{\circ} \mathrm{C}$ and at $42^{\circ} \mathrm{C}$, respectively. The peak in affinity at $40^{\circ} \mathrm{C}$ is, unlike the DENV-2 system, due to both high $\mathrm{k}_{\text {on }}$ rates and to more favorable enthalpic contribution to binding, compared to the measurements at $37^{\circ} \mathrm{C}$ and at 
$42^{\circ} \mathrm{C}$. While the structure of the antigen-binding site for this malaria immune complex is unknown, our measurements indicate that larger unfavorable entropy values obtained at $37^{\circ} \mathrm{C}$ and $42^{\circ} \mathrm{C}$, compared to results at $40^{\circ} \mathrm{C}$. Such effect, coupled with the overall positive heat capacity change of the reaction, are suggestive of predominantly hydrophobic solvation dominated by both unfavorable enthalpy and a consequence of favorable entropy (20).

We have not detected with Circular Dichroism experiments significant secondary structure modifications in any protein partner or complex, across the temperature range here used (Figure S1). The differences in affinities that we measured between the two techniques have previously been reported for a malaria system involving MSP1 (21). These discrepancies may be accounted for by the presence of the adsorbed phase in ELISA measurements that could hinder epitope binding, produce steric or attractive interactions between the mAb molecules (22) themselves or induce blocking of binding sites by multivalent binding and rebinding (23). These restrictions may be reduced for thermally equilibrated ELISA samples, resulting in higher affinities compared to ITC results or non-equilibrated ELISA data (Table 1).

In conclusion, our data indicate the potential for reversible, physiological fever temperatures in augmenting antibody affinity in vitro for tertiary and quaternary epitopes. This new role may constitute an important adaptive mechanism for antibody-mediated detection and protection against pathogens. Further validation by in vivo studies and extension to a larger set of antigens involved in fever episodes, including from bacterial pathogens, will extend the reach of our conclusions. In addition, our results may add to the growing interest in relating hyperthermia to the efficiency of cancer immunotherapy (24). Finally, active thermal equilibration of protein partners prior to performing ELISA or other relevant in vitro assays is proposed to improve on binding affinities and assist in cases where limited amounts of samples are available. 


\section{Methods}

\section{Enzyme-linked immunosorbent assays (ELISA)}

\section{ELISA measurements with dengue DENV-2 antigen and antibody}

ELISA with solid-phase bound NS1 protein were carried out as previously described (8). Briefly, polystyrene Maxisorp microplatesNunc were coated overnight at $37^{\circ} \mathrm{C}, 40^{\circ} \mathrm{C}$ or $42^{\circ} \mathrm{C}$ with a purified recombinant NS1 expressed in Escherichia coli (400 ng/well) in triplicates. The plates were washed 3 times with phosphate-buffered saline (PBS) containing $0.05 \%$ Tween-20 (PBST) and blocked with 1xPBST containing 3\% skim milk and $0.1 \%$ of BSA for 2 hours at $37^{\circ} \mathrm{C}$ or $40^{\circ} \mathrm{C}$. After a new wash cycle, the anti-NS1 mAb 4F6 (11) was diluted $(\log 2)$ starting at $157.3 \mathrm{nM}$, added to wells and incubated at $37^{\circ} \mathrm{C}$ or $40^{\circ} \mathrm{C}$ for 2 hours. After a new wash cycle, the anti-mouse IgG antibody conjugated to peroxidase (Sigma, USA) was added to wells and incubated again for 2 hours at $20 \pm 2^{\circ} \mathrm{C}$. After a final washing cycle, plates were developed with sodium citrate buffer $(\mathrm{pH} 5.8)$ containing ortho-phenylenediamine dihydrochloride (OPD) (Sigma, USA) and $\mathrm{H}_{2} \mathrm{O}_{2}$ and the reaction was stopped after 15 min with the addition of $50 \mu \mathrm{l}$ of $\mathrm{H}_{2} \mathrm{SO}_{4}$ at $2 \mathrm{M}$. The optical density reading was performed at 492 nm plate reader (Labsystems Multiscan, Thermo-Scientific, USA).

\section{ELISA measurements with malaria PvMSP1 $_{19}$ antigen and antibody}

Recombinant protein PvMSP1 $1_{19}$ was kept at $37^{\circ} \mathrm{C}, 40^{\circ} \mathrm{C}$ or $42^{\circ} \mathrm{C}$ for 1 hour prior to ELISA assays. The recombinant protein was employed as solid phase-bound antigen (200 ng/well) and a volume of $50 \mu \mathrm{l}$ of each solution was added to each well of 96-well plates (BD Costar 3590). After overnight incubation at each indicated temperature, the plates were washed with PBST and blocked with 5\% milk-2.5\% BSA for 2 hours, at each specified temperature. The plates were washed with PBST and the monoclonal antibody $\mathrm{K}_{2} 3$ (10) was tested at serial dilutions (2x) initiating at $93.32 \mathrm{nM}$ in a final volume of $50 \mu \mathrm{l}$ of sample added to each well in triplicate, followed by incubation for 1 hour at each temperature. After washes with PBST, $50 \mu \mathrm{l}$ of a solution containing anti-mouse IgG (KPL) conjugated to peroxidase diluted 1:3.000 was added to each well and incubated at $20 \pm 2^{\circ} \mathrm{C}$ for 1 hour. The enzymatic reaction was developed using 3,3', 5,5'tetramethylbenzidine (TMB) (Bio-Rad)) for 15 minutes and stopped using $\mathrm{H}_{2} \mathrm{SO}_{4} 1 \mathrm{~N}$. The optical density values were determined at $450 \mathrm{~nm}$. 
All ELISA data was analyzed using Prism 7 (GraphPad, USA). Background-subtracted data represent averages of two to three independent readings.

\section{Circular dichroism (CD)}

CD measurements were performed in a JASCO-810 spectrometer (Jasco, Japan) coupled to a Peltier temperature controller (Model JWJTC-484). Immunocomplexes $(0.064 \mathrm{mg} / \mathrm{ml}$ $\mathrm{MSP}_{19}$ with $0.256 \mathrm{mg} / \mathrm{ml} \mathrm{IgG} \mathrm{K}_{2} 3$, and $0.128 \mathrm{mg} / \mathrm{ml} \mathrm{NS1}$ with $0.64 \mathrm{mg} / \mathrm{ml} \mathrm{IgG} 4 \mathrm{H} 1 \mathrm{BC}$, respectively) were reconstituted at $20 \pm 2^{\circ} \mathrm{C}$. Three hundred $\mu \mathrm{l}$ of each complex were immediately thereafter placed in the 1-mm CD cell for 1 hour at specified temperatures, prior to data acquisition. All measurements were performed in $10 \mathrm{mM}$ PBS, $\mathrm{pH} 7.4$, containing 1 $\mathrm{mM}$ 2-mercaptoethanol. Data were averaged from three scans at $100 \mathrm{~nm} / \mathrm{min}$, data pitch 0.1 $\mathrm{nm}$, bandwidth $1 \mathrm{~nm}$. Buffer baselines were subtracted from respective sample spectra.

\section{Isothermal titration calorimetry (ITC)}

Protein concentrations were determined spectrophotometrically by measuring the absorbance at $280 \mathrm{~nm}$ (NanoDrop 2000, Thermo-Scientific, USA). Molar absorption coefficients for all proteins were calculated with ProtParam (SIB, Switzerland). ITC measurements were performed on a MicroCaliTC 200 calorimeter (GE Healthcare, USA). The heat signals due toprotein-protein binding were obtained as the difference betweenthe heat of reaction and the corresponding heat of dilution, using Microcal Origin v7.0 (OriginPro, USA). Thermodynamic and kinetic values based on ITC data were obtained using KinITC (25) (Affinimeter, Spain). All titrations comprised of antigen in syringe at $7 \mu \mathrm{M}$ (NS1) or $1 \mu \mathrm{M}$ $\left(\mathrm{MSP}_{19}\right)$ and $10 \mu \mathrm{M}$ (anti-NS1 IgG) or $1 \mu \mathrm{M}$ (anti-MSP1 $\left.{ }_{19} \mathrm{IgG}\right)$ in the cell, respectively. All measurements were performed in $100 \mathrm{mM}$ PBS, pH 7.4, with $1 \mathrm{mM}$ of 2-mercaptoethanol. IgGs were kept in iTC200 cell at each indicated temperature for 1 hour prior to measurements. Antigens were separately heated for the same period in $200 \mu \mathrm{L}$ Eppendorf microcentrifuge tubes in a water bath (Thermo-Scientific, USA) before start of titrations. 
Supporting Information Available: Circular Dichroism data are included in the supporting information.

\section{Acknowledgments}

We thank Dr. Iolanda M. Cuccovia and Dr. Michael McLeish for critical reading of the manuscript. We appreciate the technical support from Darshak Bhatt and Eneas de Carvalho. This study was funded by the Brazilian National Council for Scientific and Technological Development (400662/2014-0 for R.C.S. and 309041/2012-0 for M.M.D.C.) and São Paulo Research Foundation (2014/17595-0 for L.C.S.F.).

\section{References}

(1) Hasday JD, Garrison A (2000) Antipyretic therapy in patients with sepsis. Clin Infect Dis 31: S234-S241.

(2) Fisher DT, Vardam TD, Muhitch JB, Evans SS (2010) Fine-tuning immune surveillance by fever-range thermal stress. Immunol Res 46: 177-88.

(3) Evanss SS, Repasky EA, Fisher DT (2016) Fever and the thermal regulation of immunity: the immune system feels the heat. Nat Rev Immunol 15: 335-349.

(4) Jiang Q, Cross AS, Singh IS, Chen TT, Viscardi RM, Hasday JD (2000) Febrile core temperature is essential for optimal host defense in bacterial peritonitis. Infect Immun 63: 1265-1270.

(5) Mackowiaks PA, Browne RH, Southern PM, Smith JW (1980) Polymicrobial sepsis: an analysis of 184 cases using log linear models. Am J Med Sci 280: 73-80.

(6) St. John AL, Abraham SN, Gubler DJ (2013) Barriers to preclinical investigations of anti-dengue immunity and dengue pathogenesis. Nat Rev Microb 11: 420-426.

(7) Carlton JM (2018) Malaria parasite evolution in a test tube. Science 359: 159-160.

(8) Amorim JH, Porchia, BFMM, Balan A, Cavalcante RCM, da Costa SM, Alves AMB, Ferreira LCS (2010) Protective immunity to DENV2 after immunization with a recombinant NS1 protein using a genetically detoxified heat-labile toxin as an adjuvant. J Virol Methods 167: 186-192.

(9) Cunha MG, Rodrigues MM, Soares IS (2001) Comparison of the immunogenic properties of recombinant proteins representing the Plasmodium vivax vaccine candidate MSP1(19) expressed in distinct bacterial vectors. Vaccine 20: 385-396.

(10) Bargieri DY, Rosa DS, Braga CJM, Carvalho BO, Costa FTM, Espindola NM, Vaz AJ, Soares IS, Ferreira LCS, Rodrigues MM (2008) New malaria vaccine candidates based on the Plasmodium vivax Merozoite Surface Protein-1 and the TLR-5 agonist Salmonella Typhimurium FliC flagellin. Vaccine 26: 6132-6142.

(11) Rocha LB, Alves RPS, Caetano BA, Pereira LR, Mitsunari T, Amorim JH, Polatto JM, Botosso VF, Gallina NMF, Palacios R, Precioso AR, Granato CFH, Oliveira DBL, Silveira VB, Luz D, Ferreira LCS, Piazza RMF (2017) Epitope sequences in dengue virus NS1 protein identified by monoclonal antibodies. Antibodies 6: 14.

(12) Ovchinnikov V, Louveau JE, Barton JP, Karplus M, Chakraborty AK (2018) Role of framework mutations and antibody flexibility in the evolution of broadly neutralizing antibodies. eLife 7: e33038.

(13) Reverberi R, Reverberi L (2007) Factors affecting the antigen-antibody reaction. Blood Transfus 5: 227-240. 
(14) Hughes-Jones NC, Gardner B, Telford R (1962) The kinetics of the reaction between the blood-group antibody anti-c and erythrocytes. Biochem $J$ 85: 466-74.

(15) Chernin E (1984) The malariatherapy of neurosyphilis. J Parasitol 70: 611-617.

(16) Jones ML, Legge FS, Lebani K, Mahler SM, Young PR, Watterson D, Treutlein HR, Zeng J (2017) Computational Identification of Antibody Epitopes on the Dengue Virus NS1 Protein. Molecules 22: 607.

(17) Okazaki K, Sato T, Takano M (2012) Temperature-Enhanced Association of Proteins Due to Electrostatic Interaction: A Coarse-Grained Simulation of ActinMyosin Binding. J Am Chem Soc 134: 8918-8925.

(18) Kinoshita M, Yoshidome T (2009) Molecular origin of the negative heat capacity of hydrophilic hydration. J Chem Phys 130: 144705.

(19) Diamond MS, Pierson TC (2015) Molecular insight into dengue virus pathogenesis and its implications for disease control. Cell 162: 488-92.

(20) Prabhu NV, Sharp KA (2005) Heat capacity in proteins. Annu Rev Phys Chem 56: 521-48.

(21) Helg A, Mueller MS, Joss F, Po $\square$ ltl-Frank F, Stuart F, Robinson JA, Pluschke G (2003) Comparison of analytical methods for the evaluation of antibody responses against epitopes of polymorphic protein antigens. J Immunol Methods 276: 19-31.

(22) Nygren H, Werthen M, Stenberg M (1987) Kinetics of antibody binding to solidphase-immobilised antigen. Effect of diffusion rate limitation and steric interaction. J Immunol Methods 101 (1): 63.

(23) Neri D, Montigiani S, Kirkham PM (1996) Biophysical methods for the determination of antibody- antigen affinities. Trends Biotechnol 14: 465-470.

(24) Skitzki JJ, Repasky EA, Evans SS (2009) Hyperthermia as an immunotherapy strategy for cancer. Curr Opin Investig Drugs 10: 550-558.

(25) Burnouf D, Ennifar E, Guedich S, Puffer B, Hoffmann G, Bec G, Disdier F, Baltzinger M, Dumas P (2012) J Am Chem Soc 134: 559-565. 